УДК 94(4)

\title{
С.В. Кондратьев
}

\section{БАРРИСТЕРЫ ХVI - НАЧАЛА ХVII В.: МЕЖДУ СТЕПЕНЬЮ И ПРОФЕССИЕЙ}

\author{
Статья посвящена барристерам - студентам судебных подворий, активно превращающихся в практикующих адвокатов \\ и консультантов. Показано, что термин «барристер» использовался как для обозначения обучающегося студента (inner- \\ barrister), так и закончившего цикл обучения (upper-barrister). Обозначен переходный статус барристеров, история их эво- \\ люции, сфера профессиональной деятельности, численность, уровень доходов. \\ Ключевые слова: Англия; юристы; адвокаты; барристеры; подворья; суды; доходы.
}

Английская юриспруденция и английская адвокатура в пореформенную эпоху пережили существенные сдвиги. Реформация привела к выдавливанию из управления клириков, которых заменили юристы общего права. Секуляризация земель и богатств церкви, начавшаяся с их передачи короне, затем обернулась перераспределением имуществ среди мирян, что сопровождалось невиданным ростом земельных тяжб. Удвоение населения, общий экономический подъем, развитие торговли, доходное строительство и аренда домов в Лондоне стали еще одной причиной расширяющегося сутяжничества [1. Р. 11-12]. По общему признанию специалистов, традиционная структура профессии не могла справиться с «взрывным» увеличением дел [2. Р. 82-88; 3. Р. 52; 4. Р. 195]. «Половодье» тяжб подняло престиж юриста в обществе и привело между 1590 и 1640 гг. к росту численности судебных подворий, готовивших юристов, как минимум в пять раз [3. Р. 5]. Не получавшие земли младшие сыновья джентри стремились становиться юристами и делать карьеру в судах или органах управления [Ibid. P. 87].

В самом общем виде структура профессии в описании современника выглядит так: 12 судей общего права, около 30 сержантов (serjeants at law), около 2 тыс. практикующих юристов (counsellers) и клерки - атторнеи, солиситоры и «крючкотворы» (atturneys, solicitors, pettyfoggers) [5. Р. 25]. На вершине адвокатского сообщества находились сержанты, которые были объединены с отдельную корпорацию, монопольно вели дела в самом доходном суде королевства - Суде Общих тяжб (Court of Common Please), отличались своими мантиями и белыми шапочками [6. Р. 157-159.]. Ступенью ниже находились «подмастерья» (apprentices), которые в XIII-XIV вв. (по аналогии со средневековыми цехами) были учениками у своих мастеров-сержантов, но затем этот термин закрепился за «почтенными адвокатами» (в XV в. об этом пишет Джон Фортескью, в XVI в. Томас Уолмсли, в начале XVII в. - Эдвард Кок), не имеющими права представлять интересы клиента в Суде Общих тяжб, но допущенных в другие королевские суды [7. Р. 70; 8. Р. 312; 9. Р. 563]. Экономические и демографические реалии, растущий престиж профессии практикующего юриста привели к определенной деформации юридической корпорации. Но вот то, что источник именует адвокатами, или практикующими юристами, еще находилось в процессе становления.

Начиная с XVI в. адвокатской практикой активно начинают заниматься барристеры (barristers). Барри- стеры относительно недавно стали объектом изучения. Им посвящен краткий общий очерк Джона Бейкера и фундаментальное исследование Вильфрида Преста [10. Р. 69-76; 3. Р. 442]. Последний дал содержательный групповой портрет, произвел основательные подсчеты и выявил динамику роста численности занимающихся адвокатской практикой барристеров, а также охарактеризовал их религиозные предпочтения, участие в структурах управления страной и занятие политикой. Мы в настоящей статье намерены остановиться на социопрофессиональных характеристиках барристеров и на их неоформленном корпоративном статусе.

В отличие от сержантов и «подмастерьев», которые появились в XIII в., и обучающих юристов судебных подворий («третий университет») [11. Р. 965967], происхождение которых датируются XIV в. [2. P. 3-28], барристеры впервые упоминаются в середине XV в. в регистрах подворья Линкольн-инн, сведенных в так называемую «Черную книгу». Источник сообщает в записи за 1455 г. о неких Хэберте (Herbert) и Солиаде (Sulyard) - «лучших барристерах этого подворья» [duo de optimis barrer) [12. Р. 26]. Статут Линкольн-инна за 1466 г. выделяет «скамью» (bench), т.е. сообщество бенчеров, и «стойку», «барьер» (bar) сообщество «полных барристеров» (utter barristers). Оба сообщества должны «по общему, единому и добровольному желанию < ..> взаимодействовать, понимать, учреждать и осуществлять то, что хорошо, полезно и необходимо для общества и подворья» [Ibid. 41]. Спустя два года было специально установлено, что никто в подворье, кроме бенчера и полного барристера, не может нанимать себе клерка [Ibid. P. 49].

По мнению Дж. Бейкера, бенчеры, которые затем станут управлять подворьями, и барристеры, которые сегодня являются практикующими адвокатами, изначально таковыми не являлись. Не было профессии «бенчер» и «барристер». Он полагает, что по аналогии с университетскими степенями - бакалавр и магистр бенчеры вначале были носителями более высокой степени, которая следовала за степенью барристера [10. Р. 72, 75]. В. Прест согласен с Дж. Бейкером относительно барристеров, но воздерживается от каких-либо заключений относительно бенчеров [3. Р. 5]. Имплицитные сомнения В. Преста имеют под собой основания. В поданных в 1540-х гг. Генриху VIII Томасом Дентоном, Николосом Бэконом и Робертом Кэри предложениях по реформированию юридического образования, выделены три разряда: бенчеры (они же лекторы), полные барристеры (Utter-Barresters) и 
младшие барристеры (Inner-Barresters). Бенчеры, как сказано здесь же, это те, кто читает лекции и управляет подворьем [13. Р. 544]. Отметим условность и размытость этих аналогий. Иначе говоря, если проводить аналогии с университетами, то бенчеры, скорее, соответствуют статусу профессора. Но, как мы покажем ниже, в источниках, а не современных построениях, встречаются самые разные поименования барристеров, включая лексему «профессор».

В 1632 г. в Линкольн-инн генеральный атторней Англии Уильям Ной (William Noy) сказал: «Каждый судебный инн - это особенный университет <..>. В других университетах краткое пребывание дает право именоваться софистерами (sophisters), четырехлетнее бакалаврами, семилетнее - магистрами искусств, пребывание от 14 до 19 лет дает самое высокое и почетное имя - имя доктора. В наших правовых университетах на пятый год мы заслуживаем имя мутмэнов (mootmen) (которые напоминают детей, начавших говорить), на седьмом году или немного позднее - имя барристеров $<\ldots>$ на 27 году, прочитав первую лекцию, - имя подмастерьев права, а еще позднее, может, через 3 или 4 года, звание, которого нет выше, - сержанта (servient) права. И всякое выступление любого юриста в ходе прений в одном из судов Вестминстера есть не просто великий и умный (learning) труд, но еще и публичное представление того, что такое доктор в наших университетах» [14. Р. 144]. Такую же аналогию между степенями и рангами университетов и подворий проводит Эд. Кок [15. Р. XXXV].

Итак, мы располагаем двумя поименованиями «младшие» и «полные барристеры». Т. Дентон и др. оставили разъяснения. «Полные барристры - это те, кто в подворье во время учебных постановочных процессов (moots) за свои знания и основательность приглашаются лекторами участвовать в дискуссии и приводить аргументы по сомнительным казусам или вопросам». Их называют полными барристерами, потому что они во время упомянутых процессов сидят позади разделительной стойки, которую они называют барьером, и по своим познаниям они следуют непосредственно за бенчерами» [13. Р. 544].

«Остальные учащиеся (learners) называются младшими барристерами. Они юны, у них отсутствуют знания и основательность. Они не способны выступать и приводить резоны во время упомянутого постановочного учебного процесса». Но в ходе учебного процесса их могут приглашать садиться у барьера вместе с полными барристерами, чтобы по памяти, на юридическом французском, воспроизводить услышанные на процессе доводы [Ibidem].

В 1564 г. было установлено, что «приглашению к стойке или получению статуса полного барристера» должна предшествовать сдача неких экзаменов перед бенчерами, чтобы показывать, что студенты «приглашаются к стойке «за свои познания» (for their learning) [16. Р. 148].

Очевидно, что полный барристер это набравшийся знаний студент, который участвует в постановочных судебных процессах, и его допускают за стойку, что являлось имитацией настоящего суда, где сержанты и подмастерья приводили аргументы перед судьями.
А младший барристер - это студент, сидящей перед стойкой, фиксирующий в тетради аргументы сторон, и время от времени вызываемый для воспроизводства их [6. Р. 161]. Очевидно также, что «мутмэн» и «младший барристер» означают примерно одно и то же, а именно: студента, овладевающего правовыми знаниями в ходе различных упражнений (exercises) и еще не допущенного к стойке, чтобы участвовать в учебных постановочных процессах.

B XVI в. барристеры, пользуясь дефицитом профессиональных адвокатов и стряпчих, начинают пробовать себя на этих поприщах, т.е. начинается долгий процесс трансформации барристера из человека, получившего в подворье степень, в практикующего юриста и адвоката.

В 1532 г. парламентский статут впервые признает барристеров «знающими право» людьми [3. Р. 5]. Затем эта же формула была подтверждена статутом 1563 г. [10. Р. 75]. В 1547 г. королевская прокламация признала, что допущенные в иннах к стойкам барристеры имеют право присутствовать в судах Вестминстера [17. Р. 50]. В 1559 г. судьи судов общего права вынесли решение, что полные барристеры, после 10 лет пребывания в этом статусе, «допускаются к стойке судов Вестминстера и в Канцлерский суд», т.е. получают право вести дела в этих судах. В 1574 г. «по рекомендации Тайного совета» было решено судьями, что «никто, кроме бенчеров или барристеров», которые после допуска к стойке в течение 5 лет «постоянно пополняли свои знания или были не менее 2 лет лекторами в младшем (канцлерском. - С.К.) подворье», не может быть допущен вести дела в судах Вестминстера или составлять иски, били или прощения». В 1614 г. срок между допуском к стойке подворья и к стойке суда Вестминстера был официально сокращен судьями до 3 лет. Он мог быть еще меньшим, если полный барристер был лектором в младшем инне [16. Р. 311-312, 317-318]. В. Прест полагает, что в 1630-е гг. ограничения превратились в формальность и студенты, допущенные до стоек в своих иннах, т.е. получившие статус барристера, практически сразу же начинали практиковать [17. Р. 50-51]. В 1590 г. некий Бротон (Broughton), «подмастерье» права из Иннер-Темпла, подал в Суд Казначейства иск против принца, который, по мнению истца, не имея на это права, практиковал как адвокат в Уэльсе (а Practicer of the Law in the Marchers of Wales). Ответчик именовал себя «адвокатом и эрудитом права» (conciliarius and in lege eruddutus) и сумел доказать, что является «членом» одного из подворий и «был там студентом многие годы». Суд признал его право быть адвокатом, подчеркнув, что таковой деятельностью не могут заниматься клерки из-за «недостаточности их познаний» [18. Р. 237-238]. Иначе говоря, возник прецедент, согласно которому допуск к стойке в одном из судебных подворий предоставлял право заниматься адвокатской практикой в судах общего права и являлся свидетельством достаточной квалификации юриста. Одновременно этот же вердикт лишал такой возможности атторнеев и солиситоров, которые долгое время конкурировали с барристерами, и окончательно превращал их в стряпчих. 
Кроме Вестминстера, где барристеры выступали адвокатами сторон, за исключением закрытого для них Суда Общих тяжб, они находили себе занятие в провинциальных, манориальных, баронских судах. Поскольку барристеры не оформились как особая гильдия, они легко становились клерками различного рода администраций [17. Р. 50-51, 54].

Именно неоформленность «барристеров» и других категорий юристов, находящихся ниже имеющих свои гильдии сержантов, порождает главные трудности при их идентификации. Ибо один и тот же барристер, по замечанию Дж. Бейкера, мог выступать в разных качествах «сегодня как адвокат, а завтра как атторней», т.е. клерк [19. Р. 88-90]. На рубеже XVIXVII вв. современники нередко отмечали, что барристерам приходится выполнять обязанности клерков и, в частности, солиситоров [3. Р. 12-13]. Например, в описании судов, сделанном Р. Робинсоном в 1592 г., сказано, что в Канцлерском суде «солиситорами являются джентльмены-барристеры судебных подворий, которые, как это видно из законов нашего королевства и, судя по верной информации от их клиентов, снабжают добрыми сведениями сержантов и counsellours-at-Law для надлежащего ведения их дел» [20. Р. 13].

Иначе говоря, проблема идентификации «барристеров», «атторнеев», «солиситоров» и прочих представителей юридической профессии, скрывающихся за разными терминами, связана с тем, что две главные функции адвокатуры - представление интересов стороны в ходе судебного разбирательства и предварительное консультирование лица, обращающегося за помощью в судебное учреждение, подготовка и сочинение стандартных бумаг, их рассылка - еще окончательно не отделились друг от друга. Кроме того, обычные в Средние века прения между судьями и адвокатами с начала XVI в. вытесняются общением посредством документов. Но для того, чтобы сочинять и представлять письменные документы, не требовалось обладать статусом сержанта, подмастерья и даже барристера. Достаточно было быть атторнеем [4. Р. 19]. Возможно, именно поэтому число сержантов, несмотря на рост числа тяжб, было стабильным. «Чистыми» адвокатами в Англии XVI в. по-прежнему оставались сержанты. Что касается «барристеров» и «атторнеев», то они стремились превратиться в «чистых» адвокатов. И «барристеры», видимо, во второй половине XVI - начале XVII в. изрядно преуспели в этом, а атторнеи, напротив, были потеснены. Но полностью освободиться от секретарских функций барристеры еще не смогли. Нам, думается, вполне уместно дать такое определение «барристерам». «Барристеры» - это адвокаты, сохранившие рудименты юрисконсультских полномочий и стремящиеся от них освободиться. «Атторнеи» и «солиситоры» - это клерки и юрисконсульты, которым время от времени удавалось выступить в роли адвоката.

Подчеркнем условность наших определений. Ибо юрист, допущенный к стойке, нередко бо́льшую часть жизни оставался держателем должности, совсем или почти совсем не занимаясь адвокатурой.
Отметим еще одно обстоятельство, которое выделяли современники. Когда они пишут об адвокатах, то всегда именуют их «учеными в праве людьми» (learned in Law, eruditus in legibus terre), «знатоками права» (sages of law), «профессорами права», «людьми, ведущими тяжбу» (pleaders), но в отношении технического персонала судов и адвокатов такие термины не использовались [19. Р. 108-112; 21. Р. 71a; 22. P. 66; 31. Р. 133].

Структура не сохранившегося «Трактата об адвокате, или лице, практикующем в праве» (Treatise touching the Counseller or Practizer of the Lawes) Дж. Доддриджа позволяет судить о профессиональных обязанностях барристера. Их три: 1. «Давать “приватные” советы и консультации клиенту у себя на дому (his Private Counsell given at home in his Chamber to his Client). 2. Составление разного рода поземельных договоров (the drawing of Assurances and Conveiances, which are of sundry sorts). 3. Публичная защита интересов клиента в судах, которая осуществляется в четырех формах: письменное изложение позиции (обращение в суд), правовая аргументация, опровержение аргументов противоположной стороны, в ходе судебного разбирательства, представление фактических доказательств, защита дел в судах справедливости» (his Pleadings for his Client $<\ldots$.. > : In point of Law: In Argument of Demurrers: In matter of fact, as in giving or delivering of Evidence. And the Patronage of Causes in Courts of equitie) [23. P. The second Treatise touching the Counseller or Practizer of the Lawes, is also subdivided into three principall Parts or Sections].

Защита, отнюдь, не означала обязательного присутствия адвоката в суде. Адвокат представлял в суд позицию стороны, которая излагалась письменно на французском языке. Только нетипичные случаи требовали помощи квалифицированного барристера. Но поскольку большинство дел были стереотипными, изложить позицию (point of law) по образцам легко мог какой-нибудь атторней, а в Суде Общих тяжб или Суде Королевской скамьи - клерки, подчиненные отвечающим за фиксацию судопроизводства и составление судебных документов протонатариям (prothonotaries). В Суде Общих тяжб с этим было труднее, поскольку там действовало формальное правило, требующее, чтобы поступающие документы подписывались сержантами права. Но в Суде Королевской скамьи такое правило введут только в 1666 г. Многие барристеры специализировались на составлении стандартных документов, практиковали в своих покоях, в подворьях, и вообще не выступали за стойкой судов [3. Р. 13-14]. В середине XVII в. купец Эдмунд Лич (Edmund Leach) с грустью вспоминал те «старые времена», в которые клерки Канцелярии («находясь возрасте, когда приходит постижение законов нашей нации») составляли судебные приказы и ошибки были редки, и когда сержанты права излагали позиции сторон (speciall pleadings), что делало правосудие быстрым, не растягивающимся на годы. И противопоставлял древность современности, в которой клерки и сержанты увлечены более «прибыльным делом»: первые сочиняют отчеты, а вторые выступают за стойками судов общего права и слушают дела в 
Канцелярии. Сочинение судебных приказов и письменное изложение позиций отошло к простым «невежественным» клеркам и атторнеям, из-за чего много пропусков и ошибок в судебных приказах и биллях [24. P. 5].

Собственно то, что можно называть защитой, адвокатурой и представлением интересов стороны, у Дж. Доддриджа изложено в двух последних формах: правовая аргументация, опровержение аргументов противоположной стороны в ходе судебного разбирательства (Argument of Demurrers) и представление фактических доказательств (matter of fact, as in giving or delivering of Evidence). В ходе судоговорения и состязания с привлечением фактов доказывались, опровергались, корректировались положения, изложенные ранее письменно. Эту работу барристеры, как адвокаты сторон, часто выполняли перед судьями судов Вестминстера и судьями в ассизных округах [3. Р. 15].

Судя по свидетельству Дж. Доддриджа, быстро растущее судопроизводство в судах справедливости и прерогативных судах - Канцелярии, Палате прошений, Звездной палате, в Суде по делам опеке, Казначействе, Советах Севера и Уэльса, где судопроизводство начиналось не латинским приказом или изложением дела на французском языке, а петицией или биллем, составленным по-английски, - особенно привлекало барристеров. В отличие от Суда Общих тяжб и Суда Королевской скамьи, в которых служили сотни клерков и атторнеев, прерогативные суды и суды справедливости таковых не имели, и появившиеся вакансии поспешили заполнить люди, допущенные к стойке в судебных подворьях. Барристеры здесь также в основном занимались первоначальным письменным изложением позиций сторон, т.е. сочиняли петиции или билли, либо писали на них ответы. Кроме того, в таких судах уже существовала практика, обязательного визирования адвокатом составленного им документа [Ibid. P. 16-18].

Очевидно, что деятельность барристера (адвоката) состояла в консультировании на дому клиентов, сочинении от имени клиента судебных бумаг и представлении его интересов (защита) перед судьями в суде.

Юристы, живущие в столице, консультировали и практиковали в своих «палатах» (chambers) в подворьях либо в комнатах, которые располагались зачастую рядом с местом их проживания либо под них отводилось помещение на первом этаже дома, в котором жил юрист. Барристеры, приезжающие в Лондон из провинции на время судебных сессий, из-за дороговизны предпочитали селиться у знакомых или родственников либо снимать комнаты в одной из таверн. Видимо, это были покои, состоящие из нескольких помещений. Из-за дороговизны два барристера делили такие покои между собой, здесь же или в прихожей вели прием клиентов, в этих же покоях располагались их слуги [Ibid. Р. 40].

Роджер Норт так описывал помещения, где принимал клиентов и жил его брат Френсис Норт, тогда начинающий юрист, будущий главный судья Суда Общих тяжб и лорд-хранитель королевской печати: «После того, как Его Светлость был призван к стойке, он, перво-наперво, озаботился приобретением комнаты для адвокатской практики, которая не должна была быть выше двух пар лестничных пролетов. Комната первого этажа ценилась не так высоко, как комната, отдаленная от нее одной парой лестничных пролетов, но все-таки ее ценили выше, чем комнату, отделенную двумя пролетами, и платили соответственно. Он продал свою студенческую коморку и сдал в аренду отцовский дом, что принесло ему около 300 фунтов. С этими деньгами он начал жизнь в Элм Корт, в угловой комнате в два лестничных пролета высотой» [25. P. 54].

А вот умерший в 1580 г. Роберт Кимптон (Robert Kympton) снимал за 10 шиллингов в год в Грейз-инн покои, состоящие из палаты (Cubicle), в которой обитал с женой и дочерью, двух «кабинетов» (Studdyes), соединенных переходом, и подвала [26. Р. 31-32].

Исключительно большие покои в несколько внушительных комнат занимал в Иннер-Темпл Эд. Кок, их передал ему в пользование граф Лейстер [27. Р. 47-48].

Юристы, занятые адвокатской практикой преимущественно в провинции, принимали клиентов в кабинетах, гостиных или даже прихожих своих домов. С клиентами высокого ранга они вели дела либо по переписке через поверенных знати, либо знатные особы принимали юристов у себя в назначенное время. Провинциальный и столичный адвокат много передвигался верхом и находился в движении [3. Р. 40-42, 46].

Адвокат не мог обходиться в своей деятельности без клерка или даже нескольких клерков, занятых пересылкой корреспонденции, перепиской бумаг и составлением проектов официальных документов. Это была практическая школа, состоявшая из дальних и ближних родственников, постигающих в течение нескольких лет за стол и платье ремесло солиситора. Клерки жили в доме барристера и сопровождали его в поездках. Во время ученичества клерку не полагалось жалование. Пройдя такую школу, клерки моги стать атторнеями или солиситорами в каком-либо суде или учреждении [Ibid. 43-44]. В. Прест отмечает также, что барристеры по социальному статусу были выходцами из слоев, стоявших выше тех, из которых рекрутировались атторнеи и солиситоры [3. Р. 9].

Начиная со второй половины XVI в. подворья значительно увеличили количество допущенных к стойке студентов. В 1588 г. канцлер Англии Кристофер Хаттон сетовал, что сегодня одно подворье допускает ежегодно к стойке больше барристеров, чем все четыре во времена его молодости [28. Р. 423]. В середине XVII в. граф Кларендон утверждал, что каждый пятый из поступающих учиться в инны становится полным барристером [29. Р. 328].

Наплыв новоявленных адвокатов и юрисконсультантов вызывал у современников опасения относительно качества их подготовки и соответствия традиционным стандартам. Кр. Хаттон говорил о «неопытных», «нерадивых» и «беззаботных» молодых людях, которые становятся полными барристерами [30. Р. 220-223]. Между 1601 и 1602 гг. в Звездной палате разбиралось дело между двумя полными барристерами из Миддл-Темпла. Один из них, Кристо- 
фер Меррик (Christofer Merrike), подал иск против Роберта Пая (Robert Pye), который не отдавал долг в 5 фунтов. Пытаясь вернуть деньги, Меррик поколотил Пая и отобрал у того 56 шиллингов и роговую чернильницу. После длительных разбирательств правда восторжествовала. Роберт Пай был признан виновным и приговорен к штрафу в 1 тыс. марок, отрезанию уха и выставлению у позорного столба [31. Р. 129-133]. Эта тяжба заставила лорда Томаса Эджертона (Thomas Egerton) - хранителя большой королевской печати, заявить подворьям, что поскольку истец и ответчик являлись «профессорами права» им следует с большим тщанием отбирать тех, кого они допускают к стойке. И не допускать, как они делают, студентов «десятками и группами». Претенденты должны быть «образованы, честны и религиозны». Если бы подворья подходили к отбору таким образом, они никогда бы не приняли Пая даже в стены подворья. Ему, подчеркнул Т. Эджертон, надлежало продолжать ремесло отца, который был мясником. «Добрые и образованные профессора права - такие же добрые члены общества (Commonwealth), как и другие его члены, но невежественные профессора права такие же “опасные вредители” как кровососущие вши» (For the good and literate professors of the law are as good members of the Commonwealth as any others, but the ignorant and bad professors of the law are as 'daungerouse' Vermin' to the Commonwealth as ' Caterpillers') [Ibid. P. 133].

Судьи пытались количественно ограничить число допускаемых в подворьях к стойке. В 1596 г. они предписали иннам не допускать к стойке более 4 своих студентов в год. В 1614 г. судьи подняли эту цифру до 8 [16. Р. 314, 317].

Собранные В. Престом данные показывают, что подворья игнорировали эти предписания. Общее число барристеров, допущенных к стойке за период с 1590 по 1640 гг., по его подсчетам, составило 2293 чел. [3. Р. 84]. Другими словами, Т. Уильсон, описывая Англию на рубеже веков, был точен, говоря о двух тысячах адвокатах (counsellors). Трудно сказать, в каких пропорциях такое количество юристов, имеющих право заниматься адвокатской деятельностью, распределялось по стране. Видимо, значительная их часть была связана с центральными судами Лондона. Однако утвердиться здесь было нелегко. Это удавалось далеко не всем. Известно, что в 1560 г. только 80-90 человек регулярно вели дела в судах Вестминстера [6. Р. 28, 290 п. 1]. И если допустить, что число юристов, пробившихся через плотные ряды конкурентов к постоянной адвокатской практике, росло пропорционально числу тяжб, то к началу революции их могло быть лишь в пять раз больше, т.е. приблизительно 400-450 человек [1. Р. 182].

Однако джентльмены-барристеры находили себе применение в провинциальных графствах в качестве стюардов в манориальных судах, судей городских судов (recorders), клерков городских гильдий и корпораций, клерков провинциальных судов. Они были арбитражными управляющими (commissioners of bankruptcy), ростовщиками, крупными приобретателями земли и землевладельцами, пайщиками торговых компаний, владельцами рудников, осушителями болот [1. Р. 20].

Занимающемуся адвокатской практикой успешному столичному и провинциальному барристеру постоянно приходилось передвигаться между своими клиентами, окружными ассизными судами и наезжать в Лондон во время судебных сессий, где они, как мы видели выше, либо имели «комнаты» в подворьях, либо покупали или арендовали покои. Жизнь некоторых адвокатов была расписана буквально по часам.

Оставивший мемуары судья Суда Королевской скамьи Джеймс Уайтлок пишет, что был допущен к стойке в 1600 г. и сразу начал практиковать. В 16121614 гг., будучи барристером, ему приходилось постоянно присутствовать и вести дела клиентов в Суде Королевской скамьи, Суде Канцлера, Звездной палате, Палате Прошений [32. Р. 27, 30. 76-77]. Еще раньше, с 1608 г., барристер два раза в год (зимой и летом) вместе с разъездными судьями посещает Оксфордский судебный округ, где ведет дела своих клиентов [3. Р. 14]. В 1609 г. Дж. Уайтлок получает должность городского судьи в Вудстоке [32. Р. 19]. В 1618 г. он становится мировым судьей в Оксоне (Oxon) [Ibid. P. 62].

Адвокатская и консультационная деятельность приносила барристеру хороший доход. В первый год практика дала Дж. Уайтолку чуть больше 39 фунтов, в 1603 г. - он заработал 82 ф., в 1604 г. - 188 ф., в 1605 г. - 200 ф., в 1607 г. - 300 ф., в 1608 г. - 400 ф., 1612 - 500 ф., в 1615 г. - 600 ф. Четвертую часть денег юрист зарабатывал в Оксфордском судебном округе, во время ассизных сессий, а также активно сотрудничая с городскими судьями и советами [32. P. XIV; 33. Р. 191-197].

Подведем итог. В Англии XVI - начала XVII в. студенты подворий, получив степень полного барристера, активно вовлекались в практическую адвокатскую и консультативную деятельность. Им удалось существенно продвинуться в своих профессиональных притязаниях - вести дела в большинстве судов Вестминстера, в ассизных судах, провинциальных судах, занимать позиции в органах управления городов и провинций, служить стюардами у лордов крупных маноров. Однако предреволюционные барристеры были еще далеки от корпоративного объединения. Они оставались членами своих подворий. Барристер с широкими горизонтальными связями внутри судейской корпорации, в столичных и провинциальных кругах нарабатывал значительную клиентуру и получал высокие доходы.

\section{ЛИТЕРАТУРА}

1. Brooks C.W. Lawyers, Litigation and English Society Since 1450. London, 1998.

2. Baker J.H. Common Law Tradition. Lawyers, Books and Law. London, 2000.

3. Prest W. Rise of the Barristers. A Social History of English Bar, 1590-1640. Oxford, 1986

4. Brooks C.W. Pettyfoggers and Vipers of Commonwealth. «Lower branch» of the Legal Profession in Early Modern England. Cambridge, 1986. 
5. Wilson T. State of England, anna Dom. 1600 // Camden Miscellany. 3rd ser. London, 1936.

6. Baker J.H. Introduction to English Legal History. $4^{\text {th }}$ ed. Oxford, 2007.

7. Fortescue J. On Law and Governance of England / ed. by S. Lockwood. Cambridge, 2002.

8. Serjeant Walmsley’s description // Baker J.H. Order of Serjeants at Law. A Chronicle of Creations, with Related Texts and Historical Introduction. London, 1984.

9. Coke E. Institutes of Laws of England. London, 1832. Pt. II.

10. Baker J.H. Degree of Barrister // Baker J.H. Common Law Tradition. Lawyers, Books and Law. London, 2000.

11. Buc G. Tried University of England. Or, a Treatise of Foundations of All Colledges, Ancient Schools of Priviledges, and of Houses of Learning, and Liberall arts, within and about most Famous Cities of London // Stow J. Annales, or, A General Chronicie of England / ed. by E. Howes. Londini, 1615.

12. Records of Honorable Society of Lincoln's Inn. The Black Books. Lincoln's Inn. 1897. Vol. I.

13. Denton T., Bacon N., Cary R. To the most High and most Excellent Prince our most Gracious and most Redoubted Sovereign Lord and King Henry the Eight // Fortescutus illustratus, or, A commentary on that nervous treatise, De laudibus legum Angliæ, written by Sir John Fortescue, Knight... by Edward Waterhous, Esquire. London, 1663. P. 543-546.

14. Pearce R.R. Guide to Inns of Court and Chancery. London, 1855.

15. Coke E. Coke E. Reports. London, 1826. Vol. II, Pt. 3.

16. Dugdale W. Origines Juridicales; Or Historical Memorials of the English Laws, Courts of Justice, Forms of Tryal, Punishment in Cases Criminal, Law-Writers, Law-Books, Grants and Settlements of Estates, Degree of Serjeant, Inns of Court and Chancery. London, 1666.

17. Prest W. Inns of Court under the Elizabeth I and the Early Stuarts 1590-1640. Longman, I972.

18. Leonard W. Third part of the reports of several excellent cases of law, argued and adjudged in the courts of law at Westminster. [microform]: In the time of the late Queen Elizabeth; from the first, to the five and thirtieth year of her raign. Collected by a learned professor of the law, William Leonard, Esquire; then of the honourable society of Grays-Inne: not before imprinted; and now published by William Hughes of Grays-Inne, Esq; With alphabeticall tables of the names of the cases, and of the matters contained in the book. London, 1686.

19. Baker J. Legal Profession and Common Law: Historical essays. London, 1986.

20. Robinson R.A Briefe Collection of the Queens Majesties most High and Most Honourable Courtes of Recordes / ed. by R.L. Rickard. London, 1953. Vol. XX.

21. Coke E. Institutes of Laws of England. London, 1832. Pt. I.

22. Thynne. Of the Antiquity of Houses of Law // A Collection of curious written by the eminent antiquaries upon several heads in our English Antiquities / ed. by T. Hearn. London, 1771. Vol. l.

23. Doddridge J. English lawyer describing a method for the managing of the lawes of this land. London, 1631.

24. Leach E. Down-fall of Unjust Lawyers, with Monopolizing Officers, who have devoured much of the wealth of this nation, and the rising of the just written and proposed in order to the abolishing the chargeablenesse of proceedings in law-suits. London, 1652.

25. North R. Lives of the Right Hon. Francis North, Baron Guilford, Lord Keeper of Great Seal, under King Charles II. And King James II. London, 1826. Vol. I.

26. Abstracts of Inquisitiones post mortem relating to the city of London, returned into the Court of Chancery during the Tudor period. Part III. Elizabeth, 1577-1603 / ed. E.A. Fry. London, 1908.

27. Boyer A.D. Sir Edward Coke and Elizabethan Age. Stanford, 2003.

28. Foss E. Judges of England; with Sketches of their lives. London, 1857. Vol. 5.

29. Clarendon E. Collection of Several Tracts. London, 1727.

30. Baker J.H. Counsellors and Barristers. An Historical Study // Cambridge Law Journal. 1969. Vol. 27 , № 2.

31. Les reportes del cases in Camera Stellata, 1593 to 1609: from the original Ms. of John Hawarde / ed. by W.P. Baildon. London, 1894.

32. Famelicus of Sir James Whitelocke / ed. by J. Bruce. London, 1858.

33. Powell D.X. Sir James Whitelocks's Liber Famelicus 1570-1632: Law and Politics in Early Stuart England. Bern, 2000.

Статья представлена научной редакцией «История» 24 октября 2018 г.

Barristers of the 16th - Early 17th Centuries: Between the Degree and Profession

Vestnik Tomskogo gosudarstvennogo universiteta - Tomsk State University Journal, 2019, 447, 158-164.

DOI: $10.17223 / 15617793 / 447 / 19$

Sergey V. Kondratiev, Tyumen State University (Tyumen, Russian Federation). E-mail: sk.tm@mail.ru

Keywords: England; lawyers; counselor; barristers; Inns of Court; courts; incomes.

The article is devoted to barristers: students and graduates of judicial courts who actively became practicing counselors and consultants. The term "barrister" was used both to designate students (inner-barrister) and those called to the bar (upper-barrister). English jurisprudence and the English Bar in the post-Reformation period underwent essential changes. The multiple growth of trials required more lawyers, increased their incomes, raised the prestige of the profession. The obvious public demand increased the number of young people entering the Inns of Court (a "third university") to receive education, and led to a significant increase in the number of their graduates, i.e. upper-barristers admitted to the bar. In the 16th century, barristers, using the shortage of professional lawyers and solicitors, began to attempt themselves in these fields. Thus it was the start of a long transformation of a barrister from a person who received a degree in the Inns of Court to a practicing lawyer and a pleader. This practice was fixed in 1590 by a judicial precedent; according to it, the admission to the bar in one of the Inns of Court granted the right to practice law in the courts of common law and was evidence of a sufficient qualification of a lawyer. Barristers had the right to handle cases in the courts of Westminster (the Court of the King Bench, the Chancery, the Court of Requests, etc.), with the exception of the Court of Common Pleas, the most profitable one. Barristers accompanied judges and handled cases in assize circuits and in provincial courts. Barristers worked as members of justices of the peace in provincial counties, stewards in manorial courts, recorders in cities and towns, clerks of city guilds and corporations, attorneys in provincial courts. They were commissioners of bankruptcy, usurers, large land purchasers and landowners, shareholders of trading companies, owners of mines, men draining swamps and marshes. The author believes that barristers with wide horizontal connections inside the judiciary in the capital and provincial circles built up a significant pool of clients and received high incomes. In the 16th-17th centuries, barristers had not yet created their own professional corporation, remaining members of the Inns of Court that admitted them to the bar.

\section{REFERENCES}


2. Baker, J.H. (2000) Common Law Tradition. Lawyers, Books and Law. London: The Hambledon Press.

3. Prest, W. (1986) Rise of the Barristers. A Social History of English Bar, 1590-1640. Oxford: Clarendon Press.

4. Brooks, C.W. (1986) Pettyfoggers and Vipers of Commonwealth. "Lower branch" of the Legal Profession in Early Modern England. Cambridge: Cambridge University Press.

5. Wilson, T. (1936) State of England, Anno Dom. 1600. In: Camden Miscellany. 16:52. 3rd ser. London: London Royal Historical Society.

6. Baker, J.H. (2007) Introduction to English Legal History. 4th ed. Oxford: Butterworths.

7. Fortescue, J. (2002) On the Laws and Governance of England. Cambridge: Cambridge University Press.

8. Anon. (1984) Serjeant Walmsley's description. In: Baker, J.H. Order of Serjeants at Law. A Chronicle of Creations, with Related Texts and Historical Introduction. London: Selden Society.

9. Coke, E. (1797) Institutes of Laws of England. Pt. II. London: [s.n.].

10. Baker, J.H. (2000) Common Law Tradition. Lawyers, Books and Law. London; Rio Grande, Ohio: Hambledon Press. pp. 69-76.

11. Buc, G. (1615) Tried University of England. Or, a Treatise of Foundations of All Colledges, Ancient Schools of Priviledges, and of Houses of Learning, and Liberall arts, within and about most Famous Cities of London. In: Stow, J. Annales, or, A General Chronicie of England. Londini: [s.n.].

12. Baildon, W.P. et al. (1897) The records of the honorable society of Lincoln's Inn. The Black Books. Vol. 1. London: Lincoln's Inn.

13. Denton, T., Bacon, N. \& Cary, R. (1663) To the most High and most Excellent Prince our most Gracious and most Redoubted Sovereign Lord and King Henry the Eight. In: Waterhous, E. Fortescutus illustratus, or, A commentary on that nervous treatise, De laudibus legum Anglice, written by Sir John Fortescue, Knight. London: Printed by Tho. Roycroft for Thomas Dicas. pp. 543-546.

14. Pearce, R.R. (1855) Guide to Inns of Court and Chancery. London: Butterworths.

15. Coke, E. (1826) The Reports. Vol. II, Pt. 3. London: J. Butterworth and son.

16. Dugdale, W. (1666) Origines Juridicales; Or Historical Memorials of the English Laws, Courts of Justice, Forms of Tryal, Punishment in Cases Criminal, Law-Writers, Law-Books, Grants and Settlements of Estates, Degree of Serjeant, Inns of Court and Chancery. London: Printed by F. and T. Warren for the author.

17. Prest, W. (1972) Inns of Court under the Elizabeth I and the Early Stuarts 1590-1640. Longman.

18. Leonard, W. (1686) Third part of the reports of several excellent cases of law, argued and adjudged in the courts of law at Westminster. [microform]: In the time of the late Queen Elizabeth; from the first, to the five and thirtieth year of her raign. Collected by a learned professor of the law, William Leonard, Esquire; then of the honourable society of Grays-Inne: not before imprinted; and now published by William Hughes of Grays-Inne, Esq; With alphabeticall tables of the names of the cases, and of the matters contained in the book. London: Printed by the assigns of R. and E. Atkins, Esquires, for R. Chiswell and Tho. Roykroft.

19. Baker, J. (1986) Legal Profession and Common Law: Historical essays. London: Hambledon Continuum.

20. Robinson, R.A. (1953) Briefe Collection of the Queens Majesties most High and Most Honourable Courtes of Recordes. Vol. XX. London: Butler \& Tanner Ltd.

21. Coke, E. (1832) Institutes of Laws of England. Pt. I. London: E. \& R. Brooke.

22. Thynne. (1771) Of the Antiquity of Houses of Law. In: Hearn, T. (ed.) A Collection of curious written by the eminent antiquaries upon several heads in our English Antiquities. Vol. l. London: printed for T. Evans.

23. Doddridge, J. (1631) English lawyer describing a method for the managing of the lawes of this land. London: Printed by the Assignes of I. More, Esq.

24. Leach, E. (1652) Down-fall of Unjust Lawyers, with Monopolizing Officers, who have devoured much of the wealth of this nation, and the rising of the just written and proposed in order to the abolishing the chargeablenesse of proceedings in law-suits. London: Printed by E. Cotes.

25. North, R. (1826) Lives of the Right Hon. Francis North, Baron Guilford, Lord Keeper of Great Seal, under King Charles II. And King James II. Vol. I. London: Henry Colburn.

26. Fry, E.A. (ed.) (1908) Abstracts of Inquisitiones post mortem relating to the city of London, returned into the Court of Chancery during the Tudor period. Part III. Elizabeth, 1577-1603. London: The British record Society.

27. Boyer, A.D. (2003) Sir Edward Coke and Elizabethan Age. Stanford: Stanford University Press.

28. Foss, E. (1857) Judges of England; with Sketches of their lives. Vol. 5. London: Longmans et al.

29. Clarendon, E. (1727) Collection of Several Tracts. London: Printed for T. Woodward, and J. Peele.

30. Baker, J.H. (1969) Counsellors and Barristers. An Historical Study. Cambridge Law Journal. 27 (2).

31. Baildon, W.P. (ed.) (1894) Les reportes del cases in Camera Stellata, 1593 to 1609: from the original Ms. of John Hawarde. London: Privately printed.

32. Bruce, J. (ed.) (1858) Famelicus of Sir James Whitelocke. London: Oxford University Press.

33. Powell, D.X. (2000) Sir James Whitelocks's Liber Famelicus 1570-1632: Law and Politics in Early Stuart England. Bern: Verlag Peter Lang.

Received: 24 October 2018 